\title{
Behavior of Compacted Magnesium-Based Powders for Energy-Storage Applications
}

\author{
Daniele Mirabile Gattia ${ }^{1, *}$, Mukesh Jangir ${ }^{2}$ and Indra Prabh Jain ${ }^{2}$ a \\ 1 Department for Sustainability, ENEA, Via Anguillarese 301, 00123 Rome, Italy \\ 2 Centre for Non-Conventional Energy Resources, University of Rajasthan, Jaipur 302204, India; \\ jangirmukesh15@gmail.com (M.J.); ipjain46@gmail.com (I.P.J.) \\ * Correspondence: daniele.mirabile@enea.it
}

Received: 17 May 2020; Accepted: 23 September 2020; Published: 27 September 2020

\begin{abstract}
Energy storage is one of the main challenges to address in the near future-in particular due to the intermittent energy produced by extensive renewable energy production plants. The use of hydrides for this type of energy storage has many positive aspects. Hydride-based systems consist of absorption and desorption reactions that are strongly exothermic and endothermic, respectively. Heat management in the design of hydrogen storage tanks is an important issue, in order to ensure high-level performance in terms of the kinetics for hydrogen release/uptake and reasonable storage capacity. When loose powder is used, material in the form of pellets should be considered in order to avoid detrimental effects including decreased cycling performance. Moreover, sustainable materials in large-scale hydrogen reactors could be recovered and reused to improve any life cycle analysis of such systems. For these reasons, magnesium hydride was used in this study, as it is particularly suitable for hydrogen storage due to its high $\mathrm{H}_{2}$ storage capacity, reversibility and the low costs. Magnesium hydride was ball-milled in presence of $5 \mathrm{wt} \% \mathrm{Fe}$ as a catalyst, then compacted with an uniaxial press after the addition of expanded natural graphite (ENG). The materials underwent 45 cycles in a Sievert's type apparatus at $310^{\circ} \mathrm{C}$ and eight bar, in order to study the kinetics and cycling stability. Scanning electron microscopy was used to investigate microstructural properties and failure phenomena. Together with Rietveld analysis, X-ray diffraction was performed for phase identification and structural information. The pellets demonstrated suitable cycling stability in terms of total hydrogen storage capacity and kinetics.
\end{abstract}

Keywords: hydrogen storage; magnesium hydride; catalyst; kinetics; microstructure

\section{Introduction}

In the near future, energy storage will be one of the main issues in the field of renewable energy sources (RES). Hence, suitable energy-storage facilities must be developed [1]. For portable devices and the automotive sector, batteries are currently the best energy-storage solution while for stationary large-scale applications batteries are no longer viable and other technologies need to be explored. Another problem correlated to the use of batteries is related to raw material supply highlighting further the need for alternative energy-storage solutions [2,3]. Hydrogen is an energy vector that could be used for energy-storage applications-in particular for large-scale storage. Hydrogen can be stored as a compressed gas in large stationary tanks or underground cavities. Other options include liquid at low temperatures, or in suitable carriers such as ammonia and liquid organic hydrogen carriers (LOHCs). However, using compressed hydrogen requires large amounts of energy for the compression process. Reinforced composite materials must be used when designing the tanks. In addition, in the case of storing hydrogen in liquid form, vast amounts of energy consumption is required for hydrogen liquefaction and liquid boil off is inevitable, the system requiring the use of open tanks to avoid harmful 
overpressure [4-7]. Ammonia and liquid organic hydrogen carriers [8-11] have been considered for hydrogen storage [12,13], but an additional step is required for carrier conversion, thus limiting their use. Many hydrogen-storage methods have been studied in the past with solid state now emerging as a serious contender [14]. The main features being considered in the case of solid state hydrogen storage: storage capacity, both gravimetric and volumetric, reversibility, kinetics of reaction, cycling, material resources. Concerning hydrogen capacity, complex hydrides can store large quantities of hydrogen [15-18]. These materials include alanates, amides and borohydrides, however, their poor kinetics, thermodynamic stability, irreversibility and high decomposition temperatures restrict their practical application [19-21]. Magnesium hydride is one of the promising hydrogen-storage materials due to its high abundance, low cost, high energy density $(9 \mathrm{MJ} / \mathrm{kg} \mathrm{Mg})$, high gravimetric and volumetric hydrogen capacities, $7.6 \mathrm{wt} \% \mathrm{H}_{2}$ and $109 \mathrm{~g} \mathrm{H}_{2} / \mathrm{L}$, respectively, with reversible hydrogen sorption kinetics [22-27]. Some attempts to use magnesium-based hydrides for thermal energy storage have been reported [28-30]. A hindrance in the use of $\mathrm{MgH}_{2}$ as a hydrogen-storage material is its high thermodynamic stability requiring moderate temperature for desorption (plateau pressure at $553 \mathrm{~K}$ is one bar) and relatively slow kinetics [31,32]. In order to tune sorption kinetics and destabilize magnesium hydride different approaches have been considered such as nano-confinement [33-35], nanostructuring by ball milling [36], utilization of catalytic additives such as carbon [37,38], transition metals [39,40] and transition metal oxides [41,42] or alloying with different transition metal-like Fe [43,44], Co [45], $\mathrm{Ni}[46,47]$. Mg-based hydrides have been also investigated including $\mathrm{LaMg}_{2} \mathrm{NiH}_{7}$ [48], $\mathrm{YbMgNiH}_{4}$ [49], $\mathrm{CaMgNiH}_{4}$ [50], $\mathrm{Na}_{2} \mathrm{Mg}_{2} \mathrm{FeH}_{8}$ [51], $\mathrm{Yb}_{4} \mathrm{Mg}_{4} \mathrm{Fe}_{3} \mathrm{H}_{22}$ and $\mathrm{Ca}_{4} \mathrm{Mg}_{4} \mathrm{Fe}_{3} \mathrm{H}_{22}$ [52]. Ball milling helps to improve the kinetics of magnesium hydrides. It helps to reduce diffusion path lengths for hydrogen, to reduce particle size and increase of surface area all of which enhances the rates of hydrogen absorption/desorption. Ball milling induces defects and local imperfections in the matrix increasing nucleation sites which enhance the rate of hydrogenation of $\mathrm{MgH}_{2}$. Moreover, this process is suitable to highly disperse a catalyst within the hydride particles [53-55]. Different compounds, in particular transition metals (Ti, $\mathrm{V}, \mathrm{Cr}, \mathrm{Fe}, \mathrm{Co}, \mathrm{Ni}, \mathrm{Nb})$ [56-59] and their oxides $\left(\mathrm{TiO}_{2} \mathrm{Fe}_{2} \mathrm{O}_{3}, \mathrm{Cr}_{2} \mathrm{O}_{3}, \mathrm{~V}_{2} \mathrm{O}_{3}\right.$ and $\left.\mathrm{Nb}_{2} \mathrm{O}_{5}\right)[41,42,53,60]$, are suitable catalysts for $\mathrm{MgH}_{2}$. In particular, $\mathrm{Nb}_{2} \mathrm{O}_{5}$ showed enhanced catalytic performances [61,62]. In previous studies it has been demonstrated that $\mathrm{Fe}$, even in the form of oxides, acts as a catalyst for $\mathrm{MgH}_{2}$ sorption reactions [56-58,63,64]. Formation of $\mathrm{Mg}_{2} \mathrm{FeH}_{6}$, in particular during long time milling processes and in the case of stoichiometric Fe content, has been demonstrated and extensively studied $[29,65,66]$.

The use of non-critical raw materials for hydrogen storage can potentially become a serious issue in the case of large energy-storage facilities and scale up implementation of these technologies. In this case, magnesium and iron are geographically accessible elements on earth and bulk supply is not considered an issue in the future. In the case of magnesium, critical aspects related to contingent supply shortages and vulnerability along the supply chain remain an issue, rather than its availability [67]. Moreover, considering sustainability in a circular economy, the end of life of reactors filled with $\mathrm{MgH}_{2}-\mathrm{Fe}$ compounds could be easily managed, as these elements are environmentally compatible and they could potentially be recovered and reused. In this framework, the suitability of recovering $\mathrm{Mg}-\mathrm{Al}$ alloys and chips from magnesium processing for preparing compounds for hydrogen-storage applications has also been demonstrated [68-70].

Another important aspect for hydrogen storage is the long term cycling stability of these systems. It has been reported that the direct use of powders inside reactors is unfavorable due to long term cycling effects with the sintering of powder particles. This problem causes hydrogen-permeability reduction and consequently the formation of large volumes of inaccessible material in terms of hydrogen flow. Moreover, because of particle entrainment in the gas flow, tiny powder particles may obstruct components in the reactor, causing further malfunctions. Hence kinetics and-storage capacity inefficiency upon with cycling [71]. To overcome these issues the material within the reactor can be compressed in the form of cylindrical pellets. Aluminum, copper and carbon-based materials can also be mixed with hydride materials for improved thermal conductivity [71-76]. In fact, since desorption 
and absorption are highly endothermic and exothermic reactions (about $75 \mathrm{~kJ} / \mathrm{molH}_{2}$ in the case of $\mathrm{MgH}_{2}$ [77]), heat must be supplied to and removed from the system in order to allow the reactions to take place and prevent the slowing down of sorption reactions. It has been reported that carbon-based compounds not only increase thermal conductivity, but also enhance the mechanical properties of pellets which are affected by swelling during cycling. Due to cycling, pellets disaggregate with the formation of cracks and increasing porosity resulting in the formation of loose powder [78-82]. Use of carbon-based compounds increases mechanical stability and thermal conductivity of pellets resulting in reduced gravimetric hydrogen capacity $[16,71,75,76,83]$. Thermal conductivity of $\mathrm{MgH}_{2}$ powders can be increased from about $0.25 \mathrm{~W} / \mathrm{mK}$ to more than $4 \mathrm{~W} / \mathrm{mK}$ when compressed into pellets with $5 \mathrm{wt} \%$ ENG $[71,83]$. Another advantage of pellets is that they can be safely handled with reduced moisture and oxygen contaminations compared to loose powder [75].

In the present work, hydrogen sorption behavior and microstructural characterization of $\mathrm{MgH}_{2}-5 \mathrm{wt} \% \mathrm{Fe}-5 \mathrm{wt} \% \mathrm{ENG}\left(\mathrm{MgH}_{2}-5 \mathrm{Fe}-5 \mathrm{ENG}\right)$ pellets were studied. The results demonstrate that these pellets have suitable properties for the realization of hydrogen-storage reactors including scale up capabilities.

\section{Results and Discussions}

X-ray diffraction patterns (XRD) were obtained for $\mathrm{MgH}_{2}-5 \mathrm{Fe}-5 \mathrm{ENG}$ pellets after 20 and 45 cycles (Figure 1). Initially, the XRD shows the presence of the $\gamma-\mathrm{MgH}_{2}$ phase in the as-milled powders. However, this phase was not detected in the cycled samples. In fact, $\gamma-\mathrm{MgH}_{2}$ is a metastable phase formed only due to high energy ball milling and the results show that it disappears after cycling. The formation of $\mathrm{Mg}_{2} \mathrm{FeH}_{6}$ after ball milling and repeated cycles under hydrogen has not been observed. This compound could likely be formed in trace amounts during cycling under hydrogen pressure, but its presence was not detected by XRD. In respect to the process conditions used in these experiments, higher energy and stoichiometric $\mathrm{Mg} / \mathrm{Fe}$ ratio is required to obtain bulk formation of the phase $\mathrm{Mg}_{2} \mathrm{FeH}_{6}[65,66]$. XRD patterns and phases present in the $\mathrm{MgH}_{2}-5 \mathrm{Fe}-5 \mathrm{ENG}$ pellets after 20 and 45 cycles are shown in Figure 1. Rietveld analysis performs the full profile fitting of the pattern and it refines the crystal structure of the crystalline phases present in the sample. In Figure 1, calculated and measured XRD patterns are shown as solid red line and as black hollow dots, respectively.

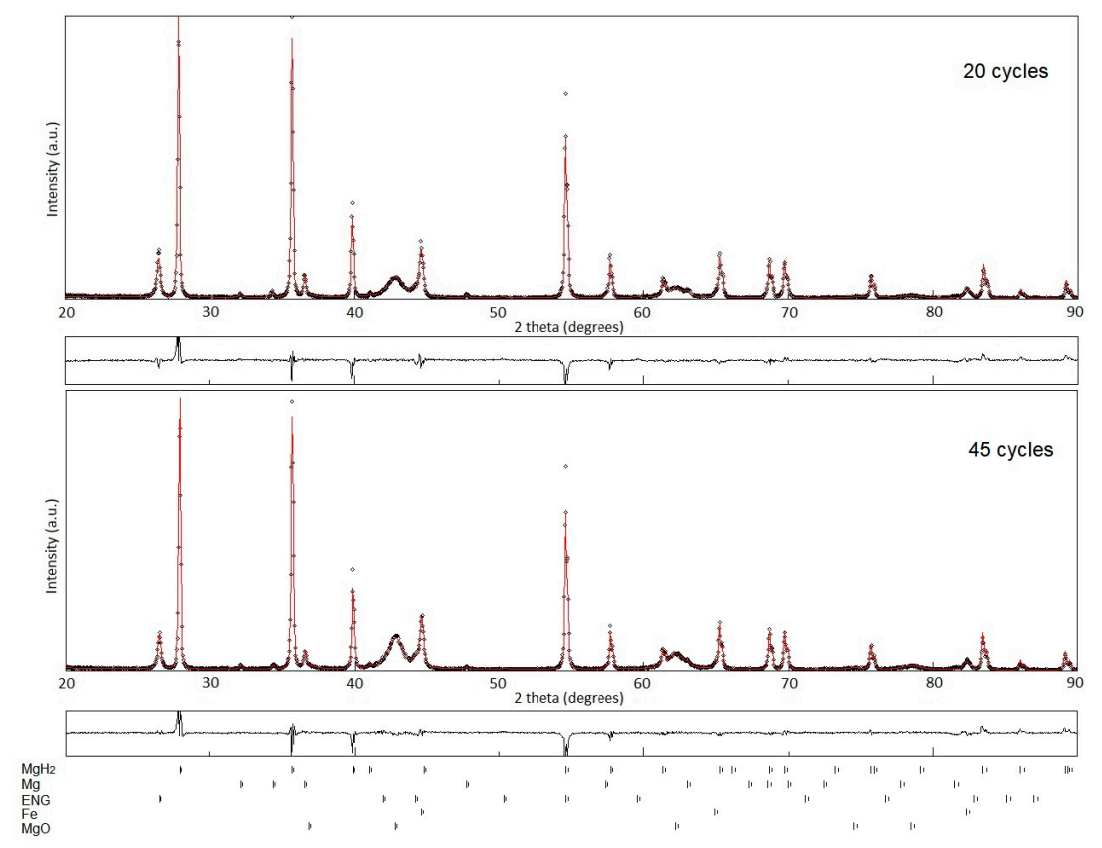

Figure 1. XRD patterns of $\mathrm{MgH}_{2}-5 \mathrm{Fe}-5 \mathrm{ENG}$ pellets after 20 and 45 cycles. Experimental (black hollow dots), calculated (solid red line) and residues are shown. 
Table 1 gives structural refinement parameters of different samples obtained by Rietveld analysis performed using MAUD software. Figure of merits for the refinements with sig $<2 \%$ and $\mathrm{Rw}<15 \%$ was considered acceptable [84]. It was observed that $\mathrm{MgH}_{2}$ crystallite size with respect to pristine $\mathrm{MgH}_{2}$, increases by an order of magnitude in the first 20 cycles and this trend slowing down with further cycling. A similar trend could be observed for $\mathrm{Mg}$, but the opposite is true in the case of $\mathrm{MgO}$ and Fe.

Table 1. Structural refinement parameters of phases present in pristine $\mathrm{MgH}_{2}$ (as-prepared), ball milled $\mathrm{MgH}_{2}, \mathrm{MgH}_{2}-5 \mathrm{Fe}-5 \mathrm{ENG}$ after 20 and 45 cycles, obtained by Rietveld refinement.

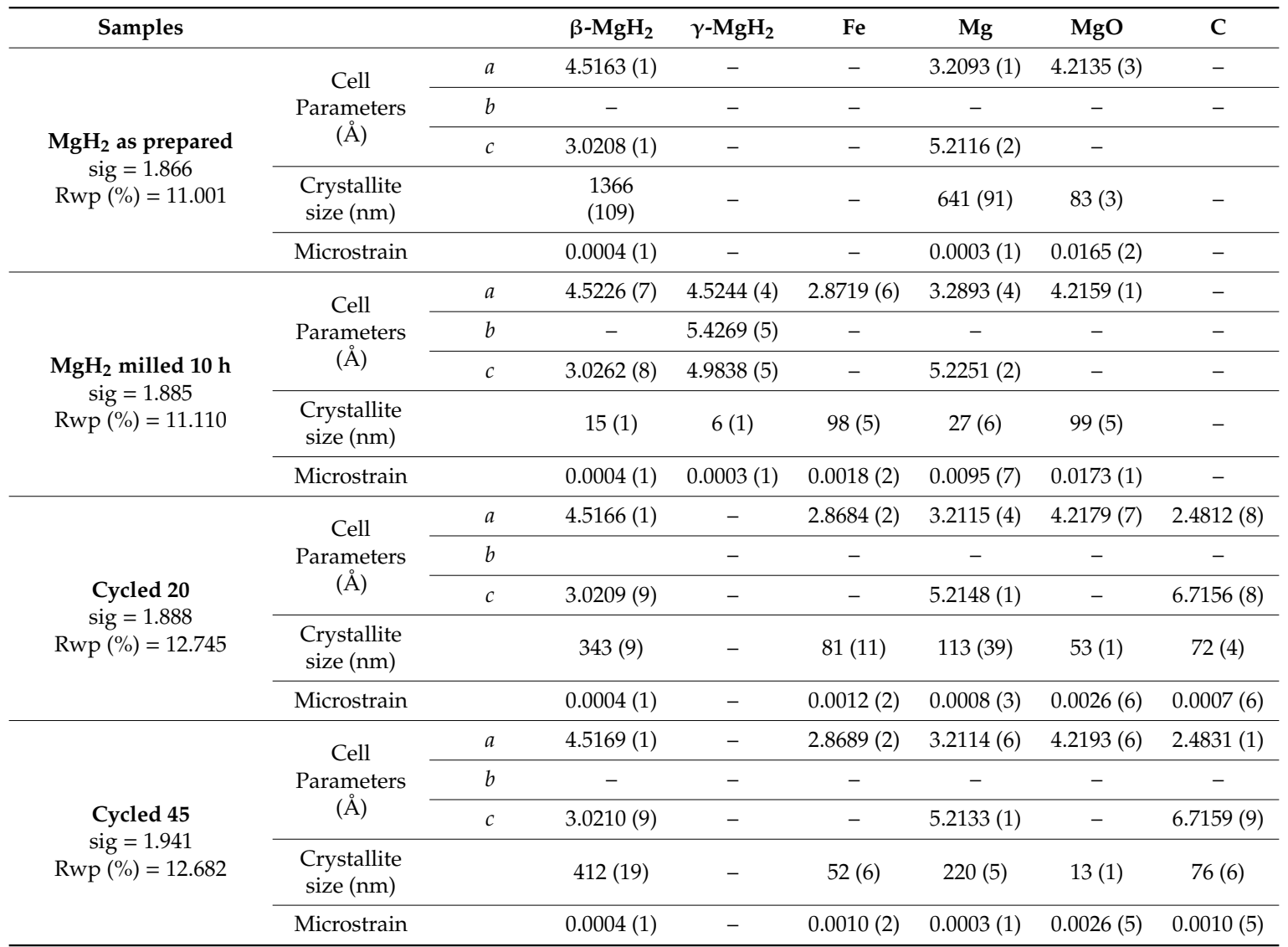

Values in parentheses are estimated standard deviations on the last significant digit.

In Figure 2, the images of the pellets before and after 20 and 45 cycles are shown. It can be seen that pellets are not heavily damaged by cycling process. The volume variation after 20 and 45 cycles is about $1.9 \%$ and $18.7 \%$, respectively.

The pellets were cycled at $310^{\circ} \mathrm{C}$ at eight-bar hydrogen pressure during absorption and 1.2 bar for desorption. Figure 3 shows the kinetics for sorption reactions indicating a slight increase in time required for desorption after 45 cycles than 20 cycles. This could have been due to $\mathrm{MgH}_{2} \mathrm{crystallite}$ coarsening which tends to stabilize with cycling. 


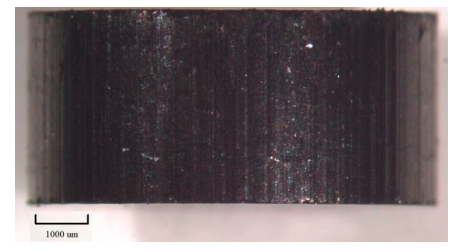

(a)

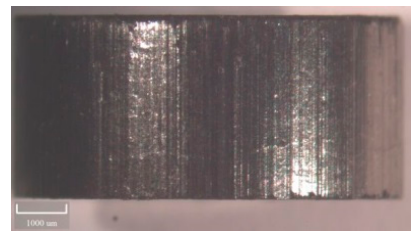

(d)

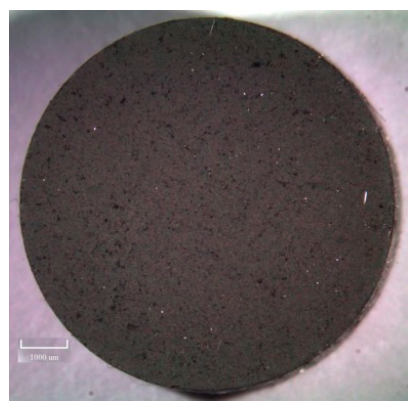

(b)

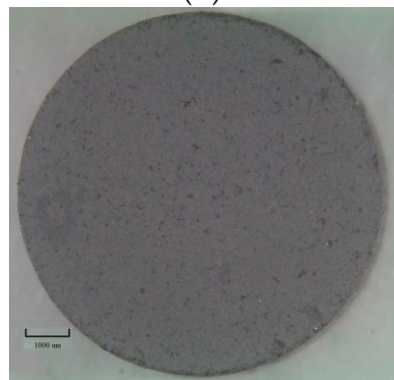

(e)

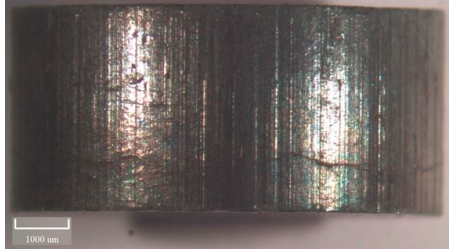

(c)

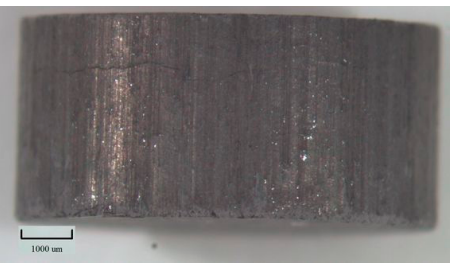

(f)

Figure 2. Pellets of $\mathrm{MgH}_{2}-5 \mathrm{Fe}-5 \mathrm{ENG}$ before (a) and after (b,c) 20 cycles; pellets before (d) and after $(\mathbf{e}, \mathbf{f}) 45$ cycles.

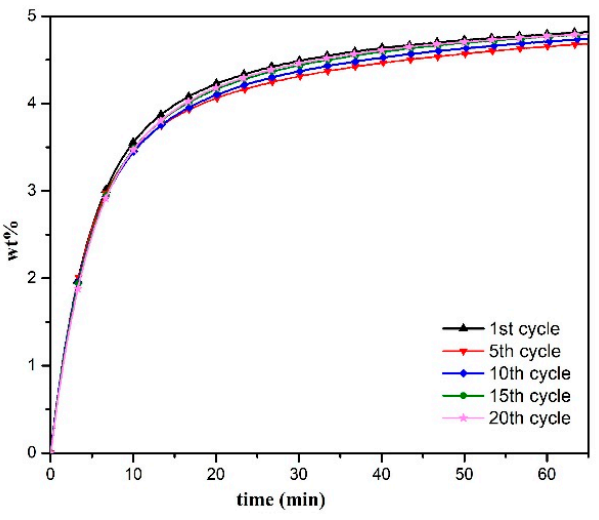

(a)

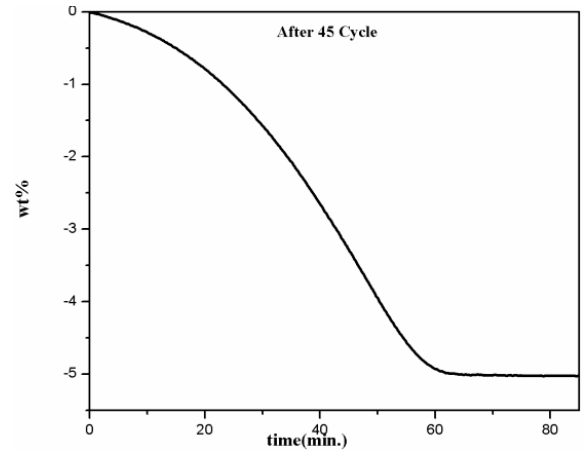

(c)

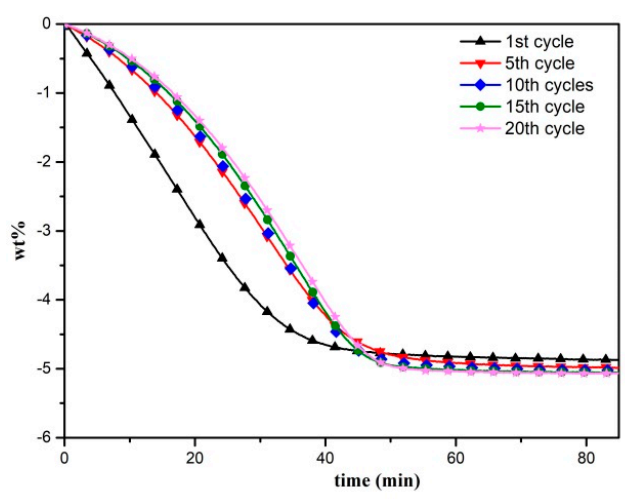

(b)

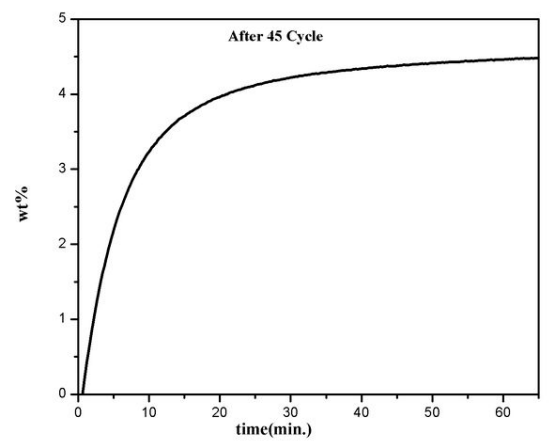

(d)

Figure 3. Desorption (a,c) and absorption (b,d) kinetics of $\mathrm{MgH}_{2}-5 \mathrm{Fe}-5 \mathrm{ENG}$ during 20 and 45 cycling measurement. 
In order to evaluate the stability due to the cycling of the pellets, wt \% vs. $t_{90}$ is shown in Figure 4. $\mathrm{t}_{90}$ is the time in minutes to reach the $90 \mathrm{wt} \%$ of $\mathrm{H}_{2}$ total capacity. The pellets demonstrated high stability in terms of hydrogen capacity and cycling kinetics, as the maximum quantity of hydrogen stored remains constant. A slight increase and decrease of $t_{90}$ during desorption and absorption respectively was observed with cycling. In the case of desorption this may be due to the coarsening of $\mathrm{MgH}_{2}$ crystallites with cycling and for absorption due to the increased porosity of the pellet, as a result of cycling, as also reported by S. Nachev et al. [78]. A similar trend has been observed for compacted powders of $\mathrm{MgH}_{2}$ ball milled with $\mathrm{Nb}_{2} \mathrm{O}_{5}$ and ENG [79].

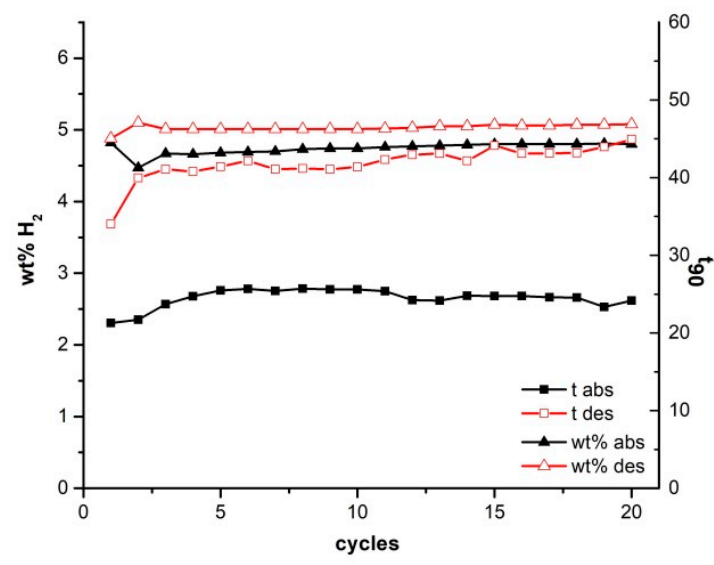

(a)

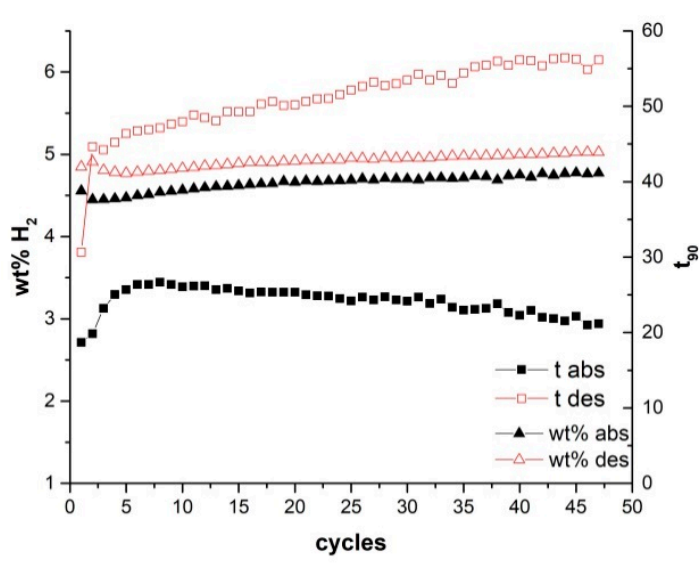

(b)

Figure 4. Hydrogen capacity vs. $t_{90}$ (time to reach $90 \mathrm{wt} \%$ of hydrogen total capacity). For $\mathrm{MgH}_{2}-5 \mathrm{Fe}-5 \mathrm{ENG}$ pellet during (a) 20 and (b) 45 cycling.

SEM micrographs were studied to highlight the microstructural features of the pellets after cycling. Figure 5a-d shows the pellets cycled after 20 and 45 cycles have no obvious cracks on the surface. Images at higher magnification of the pellet surface are shown in Figure $5 b, d$. Fe particles can be recognized in the image as the brighter particles.

In Figure 6a,b, radial and axial cross sections are shown. ENG could be identified in the images as it appears as dark strips. In radial direction ENG seems to be randomly distributed in the matrix of hydride while in the axial direction it is aligned along the direction perpendicular to the compaction axis. This microstructural configuration, which has been observed previously $[75,81]$, is particularly suitable in the case of cylindrical reactors with heat flowing in the radial direction.

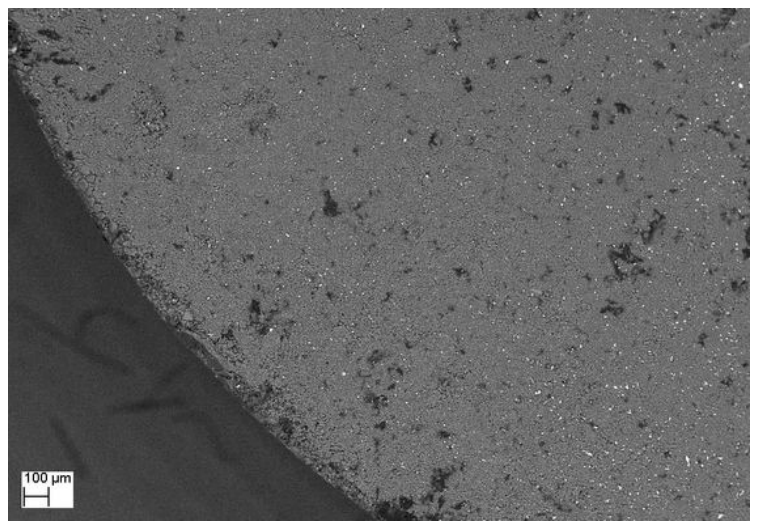

(a)

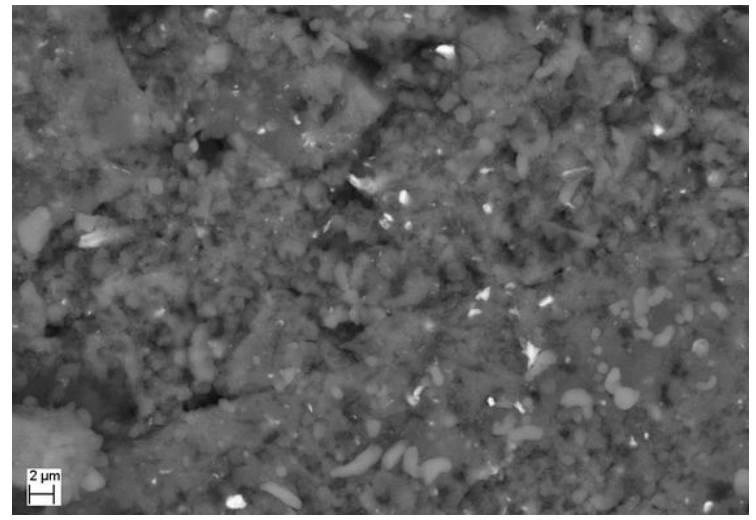

(b)

Figure 5. Cont. 


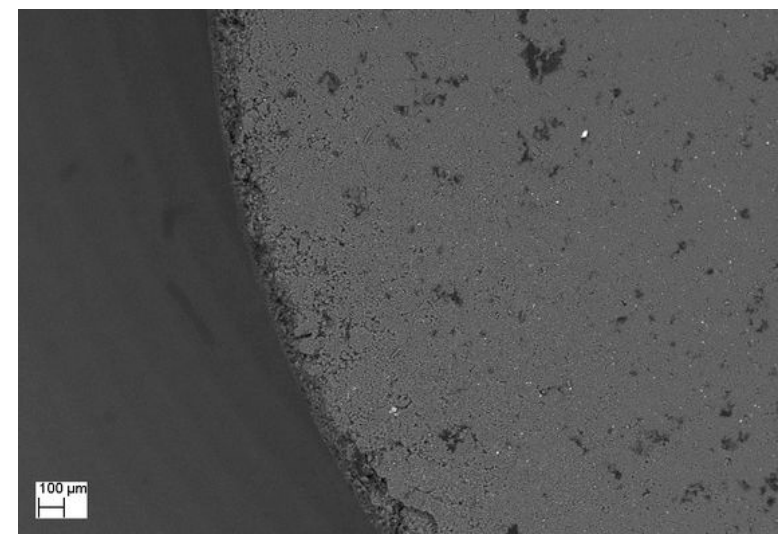

(c)

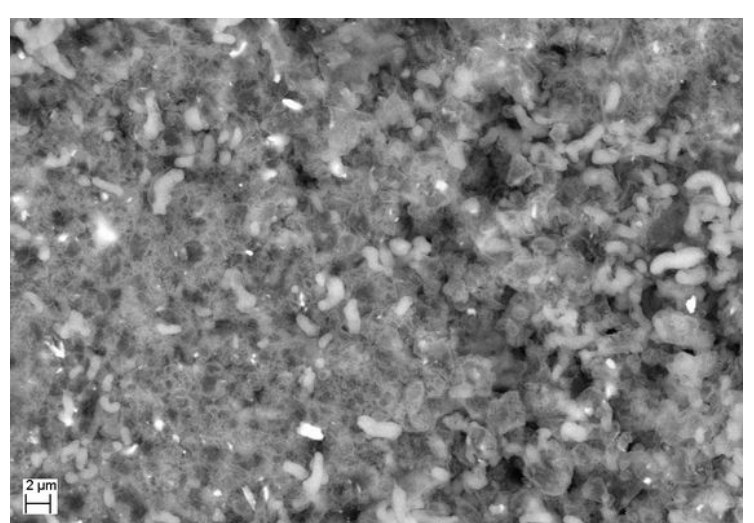

(d)

Figure 5. SEM images obtained by direct observation of the $\mathrm{MgH}_{2}-5 \mathrm{Fe}-5 \mathrm{ENG}$ pellets after $20(\mathbf{a}, \mathbf{b})$ and 45 cycles (c,d) at different magnifications.

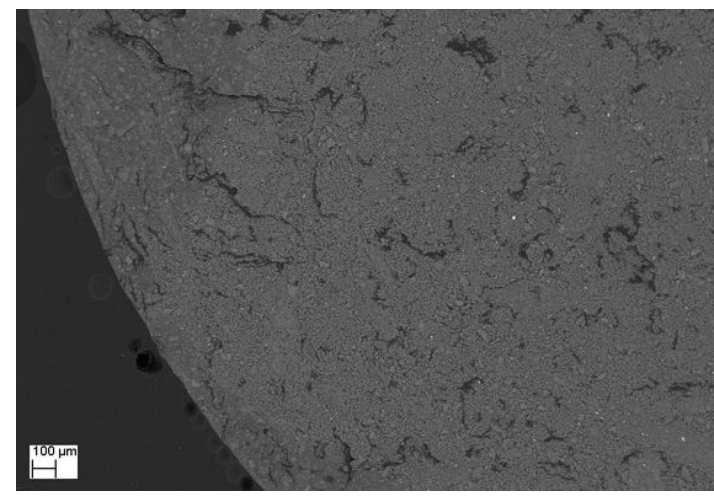

(a)

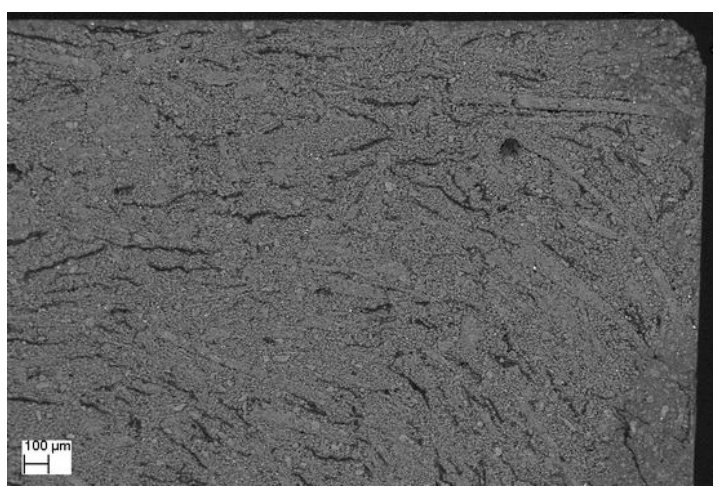

(b)

Figure 6. (a) Radial and (b) axial cross-sections of $\mathrm{MgH}_{2}-5 \mathrm{Fe}-5 \mathrm{ENG}$ compacted powder after cycling.

\section{Materials and Methods}

High purity materials were used for powder and pellet preparation: $\mathrm{MgH}_{2}(98 \%$, Alfa Aesar, Kandel, Germany), iron (Sigma-Aldrich, Darmstadt, Germany), 325 mesh and expanded natural graphite (ENG, Carbon Lorraine, La Défense, France). Sample preparation was performed following a procedure similar to that reported previously [79,85]. In order to increase matrix defects and enhance hydrogen mobility in $\mathrm{MgH}_{2}$, it was ball milled in a SPEX 8000 (SPEX, Metuchen, NJ, USA) with ball to powder ratio 10:1 for $10 \mathrm{~h}$. Before milling, $\mathrm{MgH}_{2}$ was mixed with $5 \mathrm{wt} \%$ of Fe. After milling-in order to increase thermal conductivity and mechanical stability of the pellets- $5 \mathrm{wt} \%$ of ENG, previously dried at $120^{\circ} \mathrm{C}$ under vacuum, was mixed into the $\mathrm{MgH}_{2}-5 \mathrm{Fe}$ compound by milling for $2 \mathrm{~min}$. A manual uniaxial press (Specac, Orpington, UK) was used to prepare the pellets. The powder was pressed in a $8 \mathrm{~mm}$ diameter die at $600 \mathrm{MPa}$ to prepare pellets of about $3 \mathrm{~mm}$ height. A quantity of about $250 \mathrm{mg}$ of powder was compacted. Sieverts-type apparatus (from Advanced Materials Corporation, Pittsburgh, PA, USA) was used to study the kinetics and cycling behavior. Briefly, the compound was inserted in a stainless-steel cylindrical chamber which could be positioned in a cylindrical oven and heated. The chamber was evacuated in order to remove adsorbed gases and residual moisture present on the particles surface. Ar was used as the purge gas. The chamber was heated to $120^{\circ} \mathrm{C}$ under vacuum to completely remove residual moisture present in the chamber. Successively, the sample was cycled at $310^{\circ} \mathrm{C}$ and eight bar hydrogen during absorption and 1.2 bar during desorption. The equipment monitors pressure variations and records temperature and pressure data. During absorption, every 
time the pressure decreases to a set value, the valve from a calibrated volume opens allowing hydrogen pressure to remain constant in the sample chamber. In the case of desorption, if the pressure increases automatically, the evacuation valve opens, and the hydrogen gas is removed maintaining a constant pressure. The pellets were cycled for 20 and 45 cycles in order to monitor the effects of cycling on kinetics, and in particular, the samples microstructure. After cycling, the pellets were observed by a Scanning Electron Microscope, SEM EVO MA15 (Zeiss, Oberkochen, Germany) operated at 20 kV and equipped with an X-Act silicon drift detector with AZtec analysis software (Oxford Instruments, Abingdon, UK) for energy dispersive spectroscopy (EDS) analysis. X-ray diffraction (XRD) analysis was performed on X-ray patterns obtained in a SmartLab diffractometer (Rigaku, Tokyo, Japan) equipped with a $\mathrm{Cu} \mathrm{K} \alpha$ source radiation and a diffracted beam monochromator operated at $40 \mathrm{kV}$ and $30 \mathrm{~mA}$ in Bragg-Brentano geometry. The automatic optics and sample height alignment routines were used to obtain reliable patterns. Rietveld analysis, which performs a full profile fitting, was done with the help of MAUD software [84]. Crystallite sizes were obtained for the different phases present in the samples after cycling. Images of the pellets were acquired with a stereo-microscope SZX12 (Olympus, Tokyo, Japan) equipped with calibrated digital image acquisition system.

\section{Conclusions}

The use of cheap, abundant, non-critical and environmentally friendly materials for hydrogen storage must be taken into consideration for the realization of large-scale facilities. In this work, the preparation of $\mathrm{MgH}_{2}$ with $5 \mathrm{wt} \%$ of Fe and $5 \mathrm{wt} \%$ of ENG compacted powders and their hydrogen sorption behavior are reported. $\mathrm{MgH}_{2}$ was ball milled in presence of Fe which acts as a catalyst for hydrogen sorption reactions. ENG was added to the mixture in order to enhance thermal conductivity and mechanical properties. The measurements, performed by means of a Sieverts-type apparatus, demonstrated how Fe is a suitable catalyst for Mg-based compacted powders. XRD patterns showed that $\mathrm{MgH}_{2}$ crystallite coarsening rates decreases with cycling, while Fe and $\mathrm{MgO}$ crystallite size decreases. From a microstructural point of view, no important changes were observed and the pellets demonstrated promising mechanical and hydrogen sorption properties. The concept at the base of this work is that only after the material has been optimized can the most suitable reactor design be evaluated.

Author Contributions: Conceptualization, D.M.G. and M.J. has worked for methodology, experimental investigation, writing original draft preparation, D.M.G. writing review and editing by D.M.G., M.J. and I.P.J. All authors have read and agreed to the published version of the manuscript.

Funding: This research was funded by ICTP-Abdus Salam International Center for Theoretical Physics, as one of the authors (M.J.) has benefited from a grant of the ICTP and ENEA program of Training and Research at Italian Laboratories and by Italian National Financing Program RdS PRT 2019-2021.

Conflicts of Interest: The authors declare no conflict of interest.

\section{References}

1. Moura, P.S.; de Almeida, A.T. The role of demand-side management in the grid integration of wind power. Appl. Energy 2010, 87, 2581-2588. [CrossRef]

2. Ziemann, S.; Grunwald, A.; Schebek, L.; Müller, D.B.; Weil, M. The future of mobility and its critical raw materials. Rev. Métall. 2013, 110, 47-54. [CrossRef]

3. Patricia, A.D.; Darina, B.; Claudiu, P.; Nikolaos, A. Cobalt: Demand-Supply Balances in the Transition to Electric Mobility; EUR 29381 EN; Publications Office of the European Union: Luxembourg, 2018; ISBN 978-92-79-94311-9. JRC112285. [CrossRef]

4. Andersson, J.; Grönkvist, S. Large-scale storage of hydrogen. Int. J. Hydrogen Energy 2019, 44, 11901-11919. [CrossRef]

5. Felderhoff, M.; Weidenthaler, C.; von Helmolt, R.; Eberle, U. Hydrogen storage: The remaining scientific and technological challenges. Phys. Chem. Chem. Phys. 2007, 9, 2643-2653. [CrossRef] 
6. Schlapbach, L.; Züttel, A. Hydrogen-storage materials for mobile applications. Nature 2001, 414, $353-358$. [CrossRef]

7. Møller, K.T.; Jensen, T.R.; Akibab, E.; Li, H.-W. Hydrogen-A sustainable energy carrier. Prog. Nat. Sci. Mater. Int. 2017, 27, 34-40. [CrossRef]

8. Makepeace, J.W.; He, T.; Weidenthaler, C.; Jensen, T.R.; Chang, F.; Vegge, T.; Ngene, P.; Kojima, Y.; de Jongh, P.E.; Chen, P. Reversible ammonia-based and liquid organic hydrogen carriers for high density hydrogen storage: Recent progress. Int. J. Hydrogen Energy 2019, 44, 7746-7767. [CrossRef]

9. Preuster, P.; Papp, C.; Wasserscheid, P. Liquid organic hydrogen carriers (LOHCs): Toward a hydrogen-free hydrogen economy. Acc. Chem. Res. 2017, 50, 74-85. [CrossRef]

10. Aakko-Saksa, P.T.; Cook, C.; Kiviaho, J.; Repo, T. Liquid organic hydrogen carriers for transportation and storing of renewable energy—Review and discussion. J. Power Sources 2018, 396, 803-823. [CrossRef]

11. Yoo, J.S.; Christensen, R.; Vegge, T.; Nørskov, J.K.; Studt, F. Theoretical insight into the trends that guide the electrochemical reduction of carbon dioxide to formic acid. ChemSusChem 2016, 9, 358-363. [CrossRef]

12. ACIL Allen Consulting, Opportunities for Australia from Hydrogen Exports, ACIL Allen Consulting for ARENA, 2018. Available online: https://arena.gov.au/assets/2018/08/opportunities-for-australia-fromhydrogenexports.pdf (accessed on 20 May 2020).

13. International Energy Agency. The Future of Hydrogen: Seizing Today's Opportunities, 2019. Available online: https://www.iea.org/reports/the-future-of-hydrogen (accessed on 20 May 2020).

14. Hirscher, M.; Yartys, V.A.; Baricco, M.; von Colbe, J.B.; Blanchard, D.; Bowman, R.C., Jr.; Broom, D.P.; Buckley, C.E.; Chang, F.; Chen, P.; et al. Materials for hydrogen-based energy storage-past, recent progress and future outlook. J. Alloys Compd. 2020, 827, 153548. [CrossRef]

15. Züttel, A.; Rentsch, S.; Fischer, P.; Wenger, P.; Sudan, P.; Mauron, P.; Emmenegger, C. Hydrogen storage properties of $\mathrm{LiBH}_{4}$. J. Alloys Compd. 2003, 356-357, 515-520. [CrossRef]

16. Milanese, C.; Jensen, T.R.; Hauback, B.C.; Pistidda, C.; Dornheim, M.; Yang, H.; Lombardo, L.; Züttel, A.; Filinchuk, Y.; Ngene, P.; et al. Complex hydrides for energy storage. Int. J. Hydrogen Energy 2019, 44, 7860-7874. [CrossRef]

17. Callini, E.; Atakli, Z.O.K.; Hauback, B.C.; Orimo, S.-I.; Jensen, C.; Dornheim, M.; Grant, D.; Cho, Y.W.; Chen, P.; Hjörvarsson, B.; et al. Complex and liquid hydrides for energy storage. Appl. Phys. A 2016, 122, 353. [CrossRef]

18. Ley, B.M.; Jepsen, L.H.; Lee, Y.-S.; Cho, Y.W.; Von Colbe, J.M.B.; Dornheim, M.; Rokni, M.; Jensen, J.O.; Sloth, M.; Filinchuk, Y.; et al. Complex hydrides for hydrogen storage-New perspectives. Mater. Today 2014, 17, 122-128. [CrossRef]

19. Mauron, P.; Buchter, F.; Friedrichs, O.; Remhof, A.; Bielmann, M.; Zwicky, C.N.; Züttel, A. Stability and Reversibility of $\mathrm{LiBH}_{4}$. J. Phys. Chem. B 2008, 112, 906-910. [CrossRef]

20. Møller, K.T.; Sheppard, D.; Ravnsbæk, D.B.; Buckley, C.E.; Akiba, E.; Li, H.-W.; Jensen, T.R. Complex Metal Hydrides for Hydrogen, Thermal and Electrochemical Energy Storage. Energies 2017, 10, 1645. [CrossRef]

21. Paskevicius, M.; Jepsen, L.H.; Schouwink, P.; Cerny, R.; Ravnsbaek, D.B.; Filinchuk, Y.; Dornheim, M.; Besenbacher, F.; Jensen, T.R. Metal borohydrides and derivatives-Synthesis, structure and properties. Chem. Soc. Rev. 2017, 46, 1565. [CrossRef]

22. Jain, I.; Lal, C.; Jain, A. Hydrogen storage in Mg: A most promising material. Int. J. Hydrogen Energy 2010, 35, 5133-5144. [CrossRef]

23. Dornheim, M.; Doppiu, S.; Barkhordarian, G.; Boesenberg, U.; Klassen, T.; Gutfleisch, O.; Bormann, R. Hydrogen storage in Mg based hydrides and hydride composites. Scr. Mater. 2007, 56, 841-846. [CrossRef]

24. Crivello, J.-C.; Denys, R.V.; Dornheim, M.; Felderhoff, M.; Grant, D.M.; Huot, J.; Jensen, T.R.; de Jongh, P.; Latroche, M.; Walker, G.S.; et al. Mg-based compounds for hydrogen and energy storage. Appl. Phys. A 2016, 122, 85. [CrossRef]

25. Crivello, J.-C.; Dam, B.; Denys, R.V.; Dornheim, M.; Grant, D.M.; Huot, J.; Jensen, T.R.; de Jongh, P.; Latroche, M.; Milanese, C.; et al. Review of magnesium hydride-based materials: Development and optimization. Appl. Phys. A 2016, 122, 97. [CrossRef]

26. Yartis, V.A.; Lototskyy, M.V.; Akiba, E.; Albert, R.; Antonov, V.E.; Ares, J.R.; Baricco, M.; Bourgeois, N.; Buckley, C.E.; von Colbe, J.M.B.; et al. Magnesium based materials for hydrogen based energy storage: Past, present and future. Int. J. Hydrogen Energy 2019, 44, 7809-7859. [CrossRef] 
27. Sun, Y.; Shen, C.; Lai, Q.; Liu, W.; Wang, D.-W.; Aguey-Zinsou, K.-F. Tailoring magnesium based materials for hydrogen storage through synthesis: Current state of the art. Energy Storage Mater. 2018, 10, 168-198. [CrossRef]

28. Paskevicius, M.; Sheppard, D.A.; Williamson, K.; Buckley, C.E. Metal hydride thermal heat storage prototype for concentrating solar thermal power. Energy 2015, 88, 469-477. [CrossRef]

29. Urbanczyk, R.; Peinecke, K.; Peil, S.; Felderhoff, M. Development of a heat storage demonstration unit on the basis of $\mathrm{Mg}_{2} \mathrm{FeH}_{6}$ as heat storage material and molten salt as heat transfer media. Int. J Hydrogen Energy 2017, 42, 13818-13826. [CrossRef]

30. Urbanczyk, R.; Meggouh, M.; Moury, R.; Peinecke, K.; Peil, S.; Felderhoff, M. Demonstration of $\mathrm{Mg}_{2} \mathrm{FeH}_{6}$ as heat storage material at temperatures up to $550{ }^{\circ} \mathrm{C}$. Appl. Phys. A 2016, 122, 315. [CrossRef]

31. Bogdanovič, B.; Hartwing, T.H.; Spliethoff, B. The development, testing and optimization of energy storage materials based on the $\mathrm{MgH}_{2}-\mathrm{Mg}$ system. Int. J. Hydrogen Energy 1993, 18, 575-589. [CrossRef]

32. Yuan, H.; An, Y.; Xu, G.; Chen, C. Hydriding behavior of magnesium-based hydrogen storage alloy modified by mechanical ball-milling. Mater. Chem. Phys. 2004, 83, 340-344. [CrossRef]

33. Nielsen, T.K.; Manickam, K.; Hirscher, M.; Besenbacher, F.; Jensen, T.R. Confinement of $\mathrm{MgH}_{2}$ nanoclusters within nanoporous aerogel scaffold materials. ACS Nano 2009, 3, 3521-3528. [CrossRef]

34. De Jongh, P.E.; Adelhelm, P. Nanosizing and Nanoconfinement: New Strategies towards Meeting Hydrogen Storage Goals. ChemSusChem 2010, 3, 1332-1348. [CrossRef] [PubMed]

35. Huen, P.; Paskevicius, M.; Richter, B.; Ravnsbaek, D.B.; Jensen, T.R. Hydrogen Storage Stability of Nanoconfined $\mathrm{MgH}_{2}$ upon Cycling. Inorganics 2017, 5, 57. [CrossRef]

36. Huot, J.; Tremblay, M.L.; Schulz, R. Synthesis of nanocrystalline hydrogen storage materials. J. Alloys Compd. 2003, 356-357, 603-607. [CrossRef]

37. Alsabawi, K.; Webb, T.A.; Gray, E.M.; Webb, C.J. Effect of C60 Additive on Magnesium Hydride for Hydrogen Storage. Int. J. Hydrogen Energy 2015, 40, 10508-10515. [CrossRef]

38. Bouaricha, S.; Dodelet, J.P.; Guay, D.; Huot, J.; Schulz, R. Study of the activation process of Mg-based hydrogen storage materials modified by graphite and other carbonaceous compounds. J. Mater. Res. 2011, 16, 2893-2905. [CrossRef]

39. de Rango, P.; Marty, P.; Fruchart, D. Hydrogen storage systems based on magnesium hydride: From laboratory tests to fuel cell integration. Appl. Phys. A 2016, 122, 126. [CrossRef]

40. Webb, C.J. A review of catalyst-enhanced magnesium hydride as a hydrogen storage material. J. Phys. Chem. Solids 2015, 84, 96-106. [CrossRef]

41. Aguey-Zinsou, K.-F.; Nicolaisen, T.; Fernandez, A.J.R.; Klassen, T.; Bormann, R. Effect of nanosized oxides on $\mathrm{MgH}_{2}$ (de)hydriding kinetics. J. Alloys Compd. 2007, 434-435, 738-742. [CrossRef]

42. Bhat, V.V.; Rougier, A.; Aymarda, L.; Darok, X.; Nazri, G.; Tarascon, J.M. Catalytic activity of oxides and halides on hydrogen storage of $\mathrm{MgH}_{2}$. J. Power Sources 2006, 159, 107-110. [CrossRef]

43. Bogdanovič, B.; Reiser, A.; Schlichte, K.; Spliethoff, B.; Tesche, B. Thermodynamics and dynamics of the $\mathrm{Mg}-\mathrm{Fe}-\mathrm{H}$ system and its potential for thermochemical thermal energy storage. J. Alloys Compd. 2002, 345, 77-89. [CrossRef]

44. Miwa, K.; Takagi, S.; Matsuo, M.; Orimo, S.-I. Thermodynamical stability of complex transition metal hydrides $\mathrm{Mg}_{2} \mathrm{FeH}_{6}$. J. Phys. Chem. C 2013, 117, 8014-8019. [CrossRef]

45. Norek, M.; Nielsen, T.K.; Polanski, M.; Kunce, I.; Plocinski, T.; Jaroszewicz, L.R.; Cerenius, Y.; Jensen, T.R.; Bystrzycki, J. Synthesis and decomposition mechanisms of ternary $\mathrm{Mg}_{2} \mathrm{CoH}_{5}$ studied using in situ synchrotron X-ray diffraction. Int. J. Hydrogen Energy 2011, 36, 10760-10770. [CrossRef]

46. Reilly, J.J.; Wiswall, R.H. Reaction of hydrogen with alloys of magnesium and nickel and the formation of $\mathrm{Mg}_{2} \mathrm{NiH}_{4}$. Inorg. Chem. 1968, 7, 2254-2256. [CrossRef]

47. Polanski, M.; Nielsen, T.K.; Kunce, I.; Norek, M.; Płociński, T.; Jaroszewicz, L.R.; Gundlach, C.; Jensen, T.R.; Bystrzyckia, J. $\mathrm{Mg}_{2} \mathrm{NiH}_{4}$ synthesis and decomposition reactions. Int. J. Hydrogen Energy 2013, 38, 4003-4010. [CrossRef]

48. Di Chio, M.; Ziggiotti, A.; Baricco, M. Effect of microstructure on hydrogen absorption in $\mathrm{LaMg}_{2} \mathrm{Ni}$. Intermetallics 2008, 16, 102-106. [CrossRef]

49. Huang, B.; Yvon, K.; Fischer, P. New Quaternary metal hydrides with $\mathrm{CaMgNiH}_{4}$-type structure. J. Alloys Compd. 1994, 204, L5-L8. [CrossRef] 
50. Huang, B.; Yvon, K.; Fischer, P. Calcium magnesium nickel(0) tetrahydride, $\mathrm{CaMgNiH}_{4}$, containing tetrahedral $\left[\mathrm{NiH}_{4}\right]^{4-}$ complex anions: The first quaternary transition metal hydride. J. Alloys Compd. 1992, 178, 173-179. [CrossRef]

51. Humphries, T.D.; Takagi, S.; Li, G.; Matsuo, M.; Sato, T.; Sørby, M.H.; Deledda, S.; Hauback, B.C.; Orimo, S.-I. Complex transition metal hydrides incorporating ionic hydrogen: Synthesis and characterization of $\mathrm{Na}_{2} \mathrm{Mg}_{2} \mathrm{FeH}_{8}$ and $\mathrm{Na}_{2} \mathrm{Mg}_{2} \mathrm{RuH}_{8}$. J. Alloys Compd. 2015, 645, S347-S352. [CrossRef]

52. Huang, B.; Yvon, K.; Fischer, P. Synthesis, structure and thermal stability of $\mathrm{Yb}_{4} \mathrm{Mg}_{4} \mathrm{Fe}_{3} \mathrm{H}_{2}$. J. Alloys Compd. 1993, 197, 65-68. [CrossRef]

53. Bobet, J.L.; Krawiec, S.D.; Grigorova, E.; Cansell, R.; Chevalier, B. Addition of nanosized $\mathrm{Cr}_{2} \mathrm{O}_{3}$ to magnesium for improvement of the hydrogen sorption properties. J. Alloys Compd. 2003, 351, 217. [CrossRef]

54. Huot, J.; Cuevas, F.; Deledda, S.; Edalati, K.; Filinchuk, Y.; Grosdidier, T.; Hauback, B.C.; Heere, M.; Jensen, T.R.; Latroche, M.; et al. Mechanochemistry of Metal Hydrides: Recent Advances. Materials 2019, 12, 2778. [CrossRef] [PubMed]

55. Schneemann, A. Nanostructured Metal Hydrides for Hydrogen Storage. Chem. Rev. 2018, 118, 10775-10839. [CrossRef] [PubMed]

56. Hanada, N.; Ichikawa, T.; Fujii, H. Catalytic Effect of Nanoparticle 3d-Transition Metals on Hydrogen Storage Properties in Magnesium Hydride $\mathrm{MgH}_{2}$ Prepared by Mechanical Milling. J. Phys. Chem. B 2005, 109, 7188-7194. [CrossRef] [PubMed]

57. Liang, G.; Huot, J.; Boily, S.; Van Neste, A.; Schulz, R. Catalytic effect of transition metals on hydrogen sorption in nanocrystalline ball milled $\mathrm{MgH}_{2}-\mathrm{Tm}(\mathrm{Tm}=\mathrm{Ti}, \mathrm{V}, \mathrm{Mn}, \mathrm{Fe}$ and $\mathrm{Ni})$ systems. J. Alloys Compd. 1999, 292, 247-252. [CrossRef]

58. Bassetti, A.; Bonetti, E.; Pasquini, L.; Montone, A.; Grbovic, J.; Antisari, M.V. Hydrogen desorption from ball milled $\mathrm{MgH}_{2}$ catalyzed with Fe. Eur. Phys. J. B 2005, 43, 19-27. [CrossRef]

59. Shang, C.X.; Bououdina, M.; Song, Y.; Guo, Z.X. Mechanical alloying and electronic simulations of $\left(\mathrm{MgH}_{2}+\mathrm{M}\right)$ systems $(\mathrm{M}=\mathrm{Al}, \mathrm{Ti}, \mathrm{Fe}, \mathrm{Ni}, \mathrm{Cu}$ and $\mathrm{Nb})$ for hydrogen storage. Int. J. Hydrogen Energy 2004, 29, 73-80. [CrossRef]

60. Cabo, M.; Garroni, S.; Pellicer, E.; Milanese, C.; Girella, A.; Marini, A.; Rossinyol, E.; Suriñach, S.; Baró, M.D. Hydrogen sorption performance of $\mathrm{MgH}_{2}$ doped with mesoporous nickel- and cobalt-based oxides. Int. J. Hydrogen Energy 2011, 36, 5400-5410. [CrossRef]

61. Barkhordarian, G.; Klassen, T.; Bormann, R. Fast hydrogen sorption kinetics of nanocrystalline $\mathrm{Mg}$ using $\mathrm{Nb}_{2} \mathrm{O}_{5}$ as catalyst. Scr. Mater. 2003, 49, 213-217. [CrossRef]

62. Rahman, M.W.; Castellero, A.; Enzo, S.; Livraghi, S.; Giamello, E.; Baricco, M. Effect of Mg-Nb oxides addition on hydrogen sorption in $\mathrm{MgH}_{2}$. J. Alloys Compd. 2011, 509, S438-S443. [CrossRef]

63. Montone, A.; Aurora, A.; Mirabile Gattia, D.; Antisari, M.V. Microstructural and kinetic evolution of Fe doped $\mathrm{MgH}_{2}$ during $\mathrm{H}_{2}$ cycling. Catalysts 2012, 2, 400-411. [CrossRef]

64. Mirabile Gattia, D.; Jangir, M.; Jain, I.P. Study on nanostructured $\mathrm{MgH}_{2}$ with Fe and its oxides for hydrogen storage applications. J. Alloys Compd. 2019, 801, 188-191. [CrossRef]

65. Polanski, M.; Nielsen, T.K.; Cerenius, Y.; Bystrzycki, J.; Jensen, T.R. Synthesis and decomposition mechanisms of $\mathrm{Mg}_{2} \mathrm{FeH}_{6}$ studied by in-situ synchrotron X-ray diffraction and high-pressure DSC. Int. J. Hydrogen Energy 2010, 35, 3578-3582. [CrossRef]

66. Puszkiel, J.; Gennari, F.; Larochette, P.A.; Karimi, F.; Pistidda, C.; Utke, G.R.; Jepsen, J.; Jensen, T.R.; Gundlach, C.; von Colbe, J.B. Sorption behavior of the $\mathrm{MgH}_{2}-\mathrm{Mg}_{2} \mathrm{FeH}_{6}$ hydride storage system synthesized by mechanical milling followed by sintering. Int. J. Hydrogen Energy 2013, 38, 14618-14630. [CrossRef]

67. Study on the Review of the List of Critical Raw Materials, Criticality Assessments, Final Report, European Commission 2017. Available online: https://op.europa.eu/en/publication-detail/-/publication/08fdab5f-976611e7-b92d-01aa75ed71a1 (accessed on 20 May 2020).

68. Pistidda, C.; Bergemann, N.; Wurr, J.; Rzeszutek, A.; Moller, K.T.; Hansen, B.R.S.; Garroni, S.; Horstmann, C.; Milanese, C.; Girella, A.; et al. Hydrogen storage systems from waste Mg alloys. J. Power Sources 2014, 270, 554-563. [CrossRef]

69. Hardian, R.; Pistidda, C.; Chaudhary, A.-L.; Capurso, G.; Gizer, G.; Cao, H.; Milanese, C.; Girella, A.; Santoru, A.; Yigit, D.; et al. Waste Mg-Al based alloys for hydrogen storage. Int. J. Hydrogen Energy 2018, 43, 16738-16748. [CrossRef] 
70. El-Eskandarany, M.S.; Ali, N.; Al-Salem, S.M. Solid-State conversion of magnesium waste to advanced hydrogen-storage nanopowder particles. Nanomaterials 2020, 10, 1037. [CrossRef]

71. Kim, K.J.; Montoya, B.; Razani, A.; Lee, K.H. Metal hydride compacts of improved thermal conductivity. Int. J. Hydrogen Energy 2001, 26, 609-613. [CrossRef]

72. Eaton, E.; Olsen, C.; Sheinberg, H.; Steyert, W. Mechanically stable hydride composites designed for rapid cycling. Int. J. Hydrogen Energy 1981, 6, 609-623. [CrossRef]

73. Ishikawa, H.; Oguro, K.; Kato, A.; Suzuki, H.; Ishii, E. Preparation and properties of hydrogen storage alloy-copper microcapsules. J. Less Common Met 1985, 107, 105-110. [CrossRef]

74. Khandelwal, A.; Agresti, F.; Capurso, G.; Russo, S.; Maddalena, A.; Gialanella, S.; Principi, G. Pellets of $\mathrm{MgH}_{2}$-based composites as practical material for solid state hydrogen storage. Int. J. Hydrogen Energy 2010, 35, 3565-3571. [CrossRef]

75. Pohlmann, C.; Rontzsch, L.; Kalinichenka, S.; Hutsch, T.; Kieback, B. Magnesium alloy-graphite composites with tailored heat conduction properties for hydrogen storage applications. Int. J. Hydrogen Energy 2010, 35, 12829-12836. [CrossRef]

76. Klein, H.P.; Groll, M. Heat transfer characteristics of expanded graphite matrices in metal hydride beds. Int. J. Hydrogen Energy 2004, 29, 1503-1511. [CrossRef]

77. Felderhoff, M.; Bogdanovič, B. High temperature metal hydrides as heat storage materials for solar and related applications. Int. J. Mol. Sci. 2009, 10, 325-344. [CrossRef] [PubMed]

78. Nachev, S.; de Rango, P.; Fruchart, D.; Skryabina, N.; Marty, P. Correlation between microstructural and mechanical, behavior of nanostructured $\mathrm{MgH}_{2}$ upon hydrogen cycling. J. Alloys Compd. 2015, 645, S434-S437. [CrossRef]

79. Mirabile Gattia, D.; Gizer, G.; Montone, A. Effects of the compaction pressure and of the cycling process on kinetics and microstructure of compacted $\mathrm{MgH}_{2}$-based mixtures. Int. J. Hydrogen Energy 2014, 39, 9924-9930. [CrossRef]

80. Mirabile Gattia, D.; Di Girolamo, G.; Montone, A. Microstructure, and kinetics evolution in $\mathrm{MgH}_{2}-\mathrm{TiO}_{2}$ pellets after hydrogen cycling. J. Alloys Compd. 2014, 615, S689-S692. [CrossRef]

81. Mirabile Gattia, D.; Montone, A.; Pasquini, L. Microstructure and morphology changes in $\mathrm{MgH}_{2} /$ expanded natural graphite pellets upon hydrogen cycling. Int. J. Hydrogen Energy 2013, 38, 1918-1924. [CrossRef]

82. Mirabile Gattia, D.; Montone, A.; Di Sarcina, I.; Nacucchi, M.; De Pascalis, F.; Re, M.; Pesce, E.; Antisari, M.V. On the degradation mechanisms of $\mathrm{Mg}$ hydride pellets for hydrogen storage in tanks. Int. J. Hydrogen Energy 2016, 41, 9834-9840. [CrossRef]

83. Chaise, A.; de Rango, P.; Marty, P.; Fruchart, D.; Miraglia, S.; Olives, R.; Garrier, S. Enhancement of hydrogen sorption in magnesium hydride using expanded natural graphite. Int. J. Hydrogen Energy 2009, 34, 8589-8596. [CrossRef]

84. Lutterotti, L. Total pattern fitting for the combined size-strain-stress-texture determination in thin film diffraction. Nucl. Instrum. Methods Phys. Res. Sect. B 2010, 268, 334-340. [CrossRef]

85. Mirabile Gattia, D.; Montone, A.; Di Sarcina, I. Improving magnesium based systems for efficient hydrogen storage tanks. Int. J. Hydrogen Energy 2016, 41, 14455-14460. [CrossRef]

(C) 2020 by the authors. Licensee MDPI, Basel, Switzerland. This article is an open access article distributed under the terms and conditions of the Creative Commons Attribution (CC BY) license (http://creativecommons.org/licenses/by/4.0/). 